\title{
Health Hazards of Industrial Workers: Preventive Measures
}

\section{OPEN ACCESS}

Manuscript ID:

ASH-2020-08023447

Volume: 8

Issue: 2

Month: October

Year: 2020

P-ISSN: 2321-788X

E-ISSN: 2582-0397

Received: 22.07.2020

Accepted: 05.09.2020

Published: 01.10.2020

Citation:

Sangamithra, A., and P. Sindia. "Health Hazards of Industrial Workers:

Preventive Measures." Shanlax International Journal of Arts, Science and Humanities, vol. 8, no. 2, 2020, pp. 113-115.

DOI:

https://doi.org/10.34293/ sijash.v8i2.3447

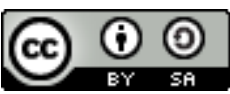

This work is licensed under a Creative Commons Attribution-ShareAlike 4.0 International License

\section{A. Sangamithra}

Professor, Department of Economics, Bharathiar University, Coimbatore, Tamil Nadu, India

(D) https://orcid.org/0000-0003-4761-8150

\section{P. Sindia}

Research Scholar, Dept. of Economics, Bharathiar University, Coimbatore, Tamil Nadu, India

\section{Abstract}

Workers in every occupation face a multitude of hazards in the work place - occupational health and. Safety addresses the broad range of workplace hazards from accident prevention to the more insidious hazards, including toxic fumes, dust, noise, heat, stress, etc. Preventing workrelated diseases and accidents must be the goal of occupational health and safety programs. The occupational health service is a link in the work organization. Human life is high in the hierarchy of values for the health professions. Health is a major determinant of the quality of life. Societal values have greater importance in the world of labor, with its complex informal and formal social structures. The cultural values of both workers and the community at large have to be considered. Present-day technology is a valuable asset if its limitations are understood. Computers and their software already provide thoroughly tested systems of data recording, processing, retrieval, and analysis, obviating the need for other records and occupational health services. The occupational illness burden is growing at an increasing rate. The profile of occupational illness has also been modified over a period due to modernization, liberalization, and globalization. Trained human resources in the field of occupational health and safety are far below the requirement. Hence, there is an urgent need for framing suitable policy, developing newer strategies, and developing our knowledge about occupational health and safety measures. Traditional training in occupational health needs to be supplemented with modern techniques.

Keywords: Liberalization, Globalization, Health, Safety and Services

\section{Introduction}

Workers in every occupation are faced with a multitude of hazards in the work place. Occupational health and. Safety addresses the broad range of workplace hazards from accident prevention to the more insidious hazards, including toxic fumes, dust, noise, heat, stress, etc. Preventing work-related diseases and accidents must be the goal of occupational health and safety programs. The occupational health service is a link in the work organization. Human life is high in the hierarchy of values for the health professions. Health is a major determinant of the quality of life. Societal values have greater importance in the world of labor, with its complex informal and formal social structures. The cultural values of both workers and the community at large have to be considered. Present-day technology is a valuable asset if its limitations are understood. Computers and their software already provide thoroughly tested systems of data recording, processing, retrieval, and analysis, obviating the need for other records and occupational health services. (Mihir Kumar Goswami and Nibedita Devi, 2000) 


\section{Categories of Occupational Hazards}

Ronald Blake has classified occupational hazards into the following three categories:

- Biological Hazards

- Environmental hazards or Physical hazards

- Psychological hazards

Biological Hazards are manifested by bacteria, fungi, viruses, insects, dietary deficiencies, drinking, allergy, brain fever imbalances, tetanus, stress and strain, infectious waste, and infestations.

\section{Environmental Hazards or Physical} Hazards include noise pollution, vibration and stocks, unsatisfactory lighting, radiation, extreme temperature, illumination, heat, ventilation, air, and water pollution. These hazards cause redness of eyes, genetic disorders, cancer, sterility, hearing, loss nerve injury, etc. to Workers.

Psychological Hazards Industrial/Job stress caused by various stressors, such as and role demands, organizational leadership, lack of group cooperation, inter-group and inter-personal conflicts, life, and career changes, etc. emotional disturbances, which in turn lead to fatigue and exhaustion. All these affect the health of employees.

\section{Preventive Measures}

Preventive measures are based on the philosophy that prevention is better than cure, which includes,

- Pre-employment medical examination

- Periodic post-employment medical examination

- Removal of hazardous conditions to the extent possible

- Surveillance of special classes of workers such as women workers and child laborers exposed to health hazards

- Emergency treatment in case of accidents

- Health and hygiene education for the workers

- Training in first-aid to workers

- Proper factory lay-out and illumination

- Proper effluent disposal treatment plants

- Proper re-design of a job to remove monetary and fatigue

- Proper scheduling of the work with adequate rest

\section{Conclusion}

The occupational illness burden is growing at an increasing rate. The profile of occupational illness has also modified over some time due to modernization, liberalization, and globalization. Trained human resources in the field of occupational health and safety are far below the requirement. Hence, there is an urgent need for framing suitable policy, developing newer strategies, and developing our knowledge about occupational health and safety measures. Traditional training in occupational health needs to be supplemented with modern techniques.

\section{References}

Ahmad, Iftikhar. "Occupational Health and Safety in Industries in Developing World." Gomal Journal of Medical Sciences, vol. 14, no. 4, 2016, pp. 223-228.

Deepa, V.D. "Informal Sector Employment in the Manufacturing Sector in Kerala." Paripex - Indian Journal of Research, vol. 7, no. 10, 2018, pp. 27-32.

Goswami, Mihir Kumar, and Nibedita Devi. "Occupational Health with Special Reference to Lung Problems." Journal of Evidence based Medicine and Healthcare, vol. 2, no. 45, 2015, pp. 8196-8203.

Hagedorn, Jenn, et al. "The Role of Labor Unions in Creating Working Conditions That Promote Public Health." American Journal of Public Health, vol. 106, 2016, pp. 989-995.

Kambo, B.S., and Kulwinder Kaur. "Women Employment Scenario in India - Based on NSS data." Indian labour Journal, vol. 53, no. 10, 2012, pp. 961-980.

Kumar, Nomita P. "Reaching Out of Mother and Child through ICDS: Insights from a Field Study in Uttar Pradesh." Indian Journal of Human Development, vol. 11, no. 2, 2017, pp. 251-267.

Kundaragi, Prakash B., and A.M.Kadakol. "Work Stress of Employee: A Literature Review." International Journal of Advance Research and Innovative Ideas in Education, vol. 1, no. 3, 2015, pp. 18-23.

L.Sámano-Ríos, Martha., et al. "Occupational Safety and Health Interventions to Protect Young 
Workers from Hazardous Work - A Scoping Premkumar, K., etal. "A Study on Stress Management Review." Safety Science, vol. 113, 2019, and Coping Strategies with Reference to IT pp. 389-403.

Ndejjo, Rawlance. "Occupational Health Hazards among Healthcare Workers in Kampala, Companies in Tamilnadu." International Uganda." Journal of Environmental and Public Health, 2015.

Journal of Current Engineering and Scientific Research, vol. 5, no. 1, 2018, pp. 61-69.

"Protecting Workers' Health." World Health Organization, 2017.

\section{Author Details}

Dr. A. Sangamithra, Professor, Department of Economics, Bharathiar University, Coimbatore, Tamil Nadu, India, Email ID: sangamithra@buc.edu.in

P. Sindia, Research Scholar, Department of Economics, Bharathiar University, Coimbatore, Tamil Nadu, India, Email ID: sindiabenny@gmail.com 